This is a peer-reviewed, accepted author manuscript of the following research article: Kanafin, Y. N., Kakimov, Y., Adamov, A., Makhatova, A., Yeshmuratov, A., Poulopoulos, S. G., Inglezakis, V. J., \& Arkhangelsky, E. (2021). The effect of caffeine, metronidazole, and ibuprofen on continuous flow activated sludge process. Journal of Chemical Technology and Biotechnology. https://doi.org/10.1002/jctb.6658

\title{
The effect of caffeine, metronidazole and ibuprofen on continuous flow activated sludge
}

\section{process}

Yerkanat N. Kanafin ${ }^{1}$, Yerbolat Kakimov ${ }^{1}$, Assyl Adamov ${ }^{1}$, Ardak Makhatova ${ }^{1}$, Abilmansur Yeshmuratov $^{1}$, Stavros G. Poulopoulos ${ }^{1, *}$, Vassilis J. Inglezakis ${ }^{1,3, *}$, Elizabeth Arkhangelsky ${ }^{2, *}$

${ }^{1}$ Chemical and Materials Engineering Department, School of Engineering and Digital Sciences, Environmental Science \& Technology Group (ESTg), The Environment \& Resource Efficiency Cluster (EREC), Nazarbayev University, Nur-Sultan, Kazakhstan

${ }^{2}$ Civil and Environmental Engineering Department, School of Engineering and Digital Sciences, Environmental Science \& Technology Group (ESTg), The Environment \& Resource Efficiency Cluster (EREC), Nazarbayev University, Nur-Sultan, Kazakhstan

${ }^{3}$ Chemical and Process Engineering Department, Faculty of Engineering, University of Strathclyde, Glasgow, United Kingdom

Correspondence to: Dr. S. G. Poulopoulos, Chemical and Materials Engineering Department, School of Engineering and Digital Sciences, Nazarbayev University, Nur-Sultan, Kazakhstan, Email:stavros.poulopoulos@nu.edu.kz; or Dr.V.J.Inglezakis,Chemical and Process Engineering Department, Faculty of Engineering, University of Strathclyde, Glasgow, UK, Email:vasileios.inglezakis@strath.ac.uk; or Dr.Elizabeth Arkhangelsky,Civil and Environmental Engineering Department, School of Engineering and Digital Sciences, Nazarbayev University,Nur-Sultan, Kazakhstan,Email: yelyzaveta.arkhangelsky@nu.edu.kz. 


\section{Abstract}

BACKGROUND: The aim of this work was to study the biological treatment of a synthetic wastewater containing emerging contaminants. The 95-days experiment was conducted in an 81 L continuous flow conventional activated sludge apparatus consisting of anoxic and aerobic reactors with internal recycling, and a clarifier with activated sludge recycling. Real activated sludge from the municipal wastewater treatment plant in the Nur-Sultan city was used. The degradation efficiencies of caffeine, metronidazole and ibuprofen in the synthetic wastewater were studied either separately or in combination.

RESULTS: When treated separately at the concentration of $30 \mathrm{mg} / \mathrm{L}$, the degradation of caffeine and ibuprofen was up to $100 \%$, while the degradation of metronidazole ranged in $12-27 \%$. Caffeine and ibuprofen inhibited the nitrification process, while the presence of metronidazole in the system suppressed the activity of denitrifying microorganisms. The biological treatment of the synthetic wastewater containing all three compounds at the concentration of $10 \mathrm{mg} / \mathrm{L}$ each resulted in degradation of caffeine and ibuprofen up to $100 \%$, and $56 \%$ in the case of metronidazole. As both nitrification and denitrification processes were affected, the total nitrogen removal was significantly reduced from $53 \%$ to $22 \%$.

CONCLUSION: Complete degradation of caffeine and ibuprofen, and partial degradation of metronidazole were observed in a synthetic wastewater using the activated sludge process. As the presence of emerging pollutants in a wastewater affects the general efficiency of the wastewater treatment plants, the other physical or chemical pre-treatment should be utilized to minimize the harmful effect of contaminants on the biological processes.

Keywords: activated sludge; wastewater; pharmaceuticals; emerging pollutants; caffeine; metronidazole; ibuprofen 


\section{Introduction}

Emerging pollutants are naturally occurring or manmade contaminants, which are present in different environmental compartments and can significantly alter the metabolism of a living being ${ }^{1}$. Since the occurrence of emerging pollutants in the environment have been widely detected and reported, the removal of these compounds become a high-priority task for wastewater treatment plants (WWTPs) globally ${ }^{2}$. Compounds of emerging concern can enter the aquatic environment through numerous ways as they are vastly used in industry, medicine, household and agriculture ${ }^{3}$. Even at low concentrations, these compounds potentially pose an environmental and health risk, such as interference with endocrine system of high organisms, creation of drug resistance in microorganisms and accumulation in the ground, water and biomass. The main groups of emerging pollutants are pharmaceuticals, personal care products, endocrine disruptors, pesticides, surfactants and additives ${ }^{4-6}$.

Pharmaceutical compounds stand as the largest group among emerging pollutants. This group includes antibiotics, stimulant drugs, analgesics, antiseptics, fragrances, food additives, betablockers and transformation products of these compounds ${ }^{4}$. Generally, pharmaceutical compounds are found in the wastewater from hospitals, pharmaceutical manufacturing industry, agricultural waste and domestic waste ${ }^{2}$. Typically, conventional WWTPs are not designed to remove pharmaceuticals. Most of them based on the activated sludge process and they are able to effectively remove biodegradable organic contaminants. However, many pharmaceuticals are not biodegradable, while some of them exhibit recalcitrant properties ${ }^{7}$. Consequently, efficient pretreatment or post-treatment systems such as advanced oxidation processes, membrane bioreactor and membrane filtration processes have been employed to achieve complete removal of emerging pollutants in wastewaters ${ }^{8-12}$. 
Caffeine (CAF) is a naturally occurring purine alkaloid. It is widely used as a psychostimulant and coffee, tea and many other soft drinks may contain $360 \mathrm{mg} / \mathrm{L}$ of caffeine. Caffeine enters the aquatic environment through urine and household plumbing. It was detected in the groundwater samples collected from the sewage catchment of Singapore in concentrations up to $16 \mu \mathrm{g} / \mathrm{L}^{13}$. The dangerous effects of caffeine when discharged without a proper treatment in the environment have been reported extensively ${ }^{14}$. It has been found that caffeine adversely affects the digestive system and nervous system of animals, when ingested with contaminated water ${ }^{15}$. In addition, irrigation with caffeine-containing water inhibits the soil fertility ${ }^{16}$. Although it has been reported that caffeine inhibited the activity of many microorganisms, there have been also many cases where aerobic bacteria and fungi were able to successfully degrade caffeine by using it as a nitrogen source ${ }^{17-19}$. As it is seen in Table 1, methods based on biological treatment systems, such as the activated sludge process and membrane bioreactor, demonstrate high removal of caffeine $\mathrm{e}^{3,11,14,20-}$ 22 .

Metronidazole (MNZ) is the derivative of 5-nitroimidazole drugs and it is an effective antibacterial and anti-inflammatory antibiotic. It has a wide range of applications and has been detected in wastewater worldwide ${ }^{23}$. This antibiotic is low biodegradable and toxic for the environment. It is considered as potentially mutagenic and carcinogenic compound at high doses and after prolong use, while its high solubility contributes to its negative impact on the environment ${ }^{24}$. Due to its low biodegradability and antibacterial nature, metronidazole is merely removed in the conventional wastewater treatment plants. For instance, ${ }^{25}$ used the activated sludge process and achieved 34\% removal of metronidazole. Moreover, during the wastewater treatment process, it affects the growth of microorganisms present in the activated sludge and inhibits the nitrification processes, decreasing thus the general efficiency of the plant ${ }^{26,27}$. Metronidazole was 
found in hospital effluents at different concentrations $(1.8-9.4 \mu \mathrm{g} / \mathrm{L})^{28}$. In order to solve this problem, appropriate pre-treatment of metronidazole-containing wastewater should be utilized. ${ }^{24}$ used the electro-Fenton combined with the activated sludge process to achieve an $89 \%$ removal of metronidazole in wastewater.

Ibuprofen (2-(4-Isobutylphenyl) propionioc acid) (IBU) is commonly applied as a painkiller for reducing inflammation and fever. It is a non-steroidic anti-inflammatory drug and it is one of the most significantly researched pollutants among pharmaceuticals ${ }^{5,29}$. Ibuprofen has been detected at the highest concentrations in WWTPs from Viikinmäki, Finland $(16 \mu \mathrm{g} / \mathrm{L}){ }^{30}$ and Wiesbaden, Germany $(7.5 \mu \mathrm{g} / \mathrm{L})^{31}$. The presence of ibuprofen in the open water can cause endocrine-disrupting and reproduction problems in aquatic animals ${ }^{32}$. Although it was reported by ${ }^{33}$ that ibuprofen affects the biomass of the activated sludge by reducing the biological oxygen uptake and decreasing the bound of extracellular polymeric substances, the reported removal rates of ibuprofen treated by activated sludge process or membrane bioreactor were in the range 90$100 \%^{33-35}$. In addition, the common water treatment methods like sand filtration, coagulation or chlorination are reported to be not very effective in ibuprofen removal ${ }^{33}$.

Caffeine, metronidazole and ibuprofen were chosen for experiments as commonly detected emerging pollutants in wastewaters. The co-existence of these compounds was reported previously. ${ }^{36}$ found ibuprofen $(117 \mu \mathrm{g} / \mathrm{L})$ and caffeine $(4.42 \mu \mathrm{g} / \mathrm{L})$ in wastewater and metronidazole (5.44 ng/g) in biosolids of Darvill WWTP (South Africa). Liquid Chromatography with tandem mass spectrometry (LC-MS/MS) analysis of wastewater samples from urban WWTP of Gran Canario (Spain) resulted in detection of metronidazole (630 ng/L), caffeine (410 ng/L) and ibuprofen $(190 \mathrm{ng} / \mathrm{L})^{37}$. The co-existence of these compounds in high concentrations was reported for wastewater from Rinnekoti Foundation hospital in Espoo (Finland), where caffeine 
$(470 \mu \mathrm{g} / \mathrm{L})$, ibuprofen $(28 \mu \mathrm{g} / \mathrm{L})$ metronidazole $(8.9 \mu \mathrm{g} / \mathrm{L})$ were quantified using ultra-performance liquid chromatograph coupled with tandem mass spectroscopy (UPLC-MS/MS) ${ }^{38}$.

The removal efficiency of different techniques against caffeine, ibuprofen and metronidazole is presented in Table 1.

Table 1.

In this study, we aimed at evaluating the biological degradation of a synthetic wastewater containing three characteristic emerging pollutants, namely caffeine, metronidazole and ibuprofen, in a continuous flow conventional activated sludge process bioreactor. The degradation and the effect of the emerging pollutants on the activated sludge process was studied both separately for each of them and in combination, by measuring total suspended solids (TSS), total carbon (TC), total nitrogen $(\mathrm{TN})$, generation of ammonium $\left(\mathrm{NH}_{4}{ }^{+}\right)$and nitrates $\left(\mathrm{NO}_{3}{ }^{-}\right)$and the concentration of the emerging pollutants. Although there are many studies related to the biological treatment of wastewater containing emerging pollutants, only few have addressed biological treatment of caffeine, metronidazole and ibuprofen as a mixture. To the best of our knowledge the study of the combined influence of these compounds on the nitrification and denitrification in the activated sludge process has not been conducted before.

\section{Materials and Methods}

\subsection{Chemicals and wastewater composition}

To evaluate the impact of the pharmaceuticals on the efficiency of biological treatment of wastewater, the exact compositions of the synthetic wastewater was derived from the average concentration of actual municipal wastewaters ${ }^{43,44}$ and was used in the previous works ${ }^{10,45,46}$. The average TC, TN and ammonium concentrations in the final feed solution were $243.5 \pm 49.8$, 
$28.4 \pm 5.7$, and $11.4 \pm 3.6 \mathrm{mg} / \mathrm{L}$, respectively. The final $\mathrm{pH}$ of the synthetic wastewater ranged in 7.10-7.93 (Figure S.1). A volume of $5.5 \mathrm{~mL}$ of trace element solution containing $5 \mathrm{~g} / \mathrm{L} \mathrm{FeCl}_{3}, 5$ $\mathrm{g} / \mathrm{L} \mathrm{CaCl}_{2}$ and $1 \mathrm{~g} / \mathrm{L} \mathrm{KCl}$ was added in $110 \mathrm{~L}$ of synthetic wastewater. The fresh feed solution was prepared every two days using tap water. The composition of the wastewater used is shown in Table 2.

\section{Table 2.}

Lab Lemco powder was supplied by Oxoid, UK. D-Glucose anhydrous $(99.5 \% \mathrm{w} / \mathrm{w})$, ammonium bicarbonate $(99 \% \mathrm{w} / \mathrm{w})$, potassium bicarbonate $(99.9 \% \mathrm{w} / \mathrm{w})$, sodium bicarbonate $(99.9 \% \mathrm{w} / \mathrm{w})$, iron chloride anhydrous $(97 \% \mathrm{w} / \mathrm{w})$ and calcium chloride $(96 \% \mathrm{w} / \mathrm{w})$ were obtained from Fisher Scientific, USA. Analytical standards of caffeine (99\% w/w), ibuprofen ( $98 \% \mathrm{w} / \mathrm{w})$, metronidazole, and potassium chloride $(99.9 \%$ w/w) were supplied by Sigma Aldrich, USA. Sodium chloride $(98 \%$ w/w) was purchased from Altyn Orda JSC, Kazakhstan.

Metronidazole was purchased from Farmaprim LLP (Moldova) in form of suppositories, containing $500 \mathrm{mg}$ of active substance in each suppository. Ibuprofen was purchased in the form of commercial drug Ibufen D Forte (Medana Pharma, Poland), containing $200 \mathrm{mg}$ of active compound per $5 \mathrm{~mL}$ of suspension. The analytical standards were used for the high-performance liquid chromatography (HPLC) calibration while the medicinal products were used for synthetic wastewater preparation with the exception of caffeine. Ultra-pure water was supplied by the Millipore Milli-Q Ultrapure Water Purification System, Germany.

\subsection{Experimental procedure}

The experiments were conducted using the CE 705 Activated sludge process bioreactor from GUNT, Germany. The equipment consisted of raw wastewater tank (200 L), aeration tank with 
nitrification (aerobic reactor, $34 \mathrm{~L}$ ) and denitrification (anoxic reactor, $17 \mathrm{~L}$ ) zones, secondary clarifier (30 L) and treated water tank (80 L). The scheme of the reactor is shown in Figure 1.

Figure 1.

In the aeration tank, temperature was maintained at $25^{\circ} \mathrm{C}$. The flowrates of raw wastewater pump, return sludge pump and internal circulation pump were set to $2 \mathrm{~L} / \mathrm{h}, 2 \mathrm{~L} / \mathrm{h}$ and $12 \mathrm{~L} / \mathrm{h}$, respectively. The dissolved oxygen (DO) of the nitrification zone was $3.5 \pm 0.77 \mathrm{mg} / \mathrm{L}$, while the DO of the denitrification zone was equal to $0.01 \mathrm{mg} / \mathrm{L}$ throughout the experiment (Figure S.2). The recycle active sludge concentration was $4.34 \pm 2.62 \mathrm{~g} / \mathrm{L}$ and $2 \mathrm{~L}$ of waste sludge was manually removed from the bottom of the clarifier every two days. The solids residence time (SRT) was 20 days and the hydraulic retention time (HRT) was 1.06 days. The TSS in nitrification and denitrification zones was $1.86 \pm 0.5 \mathrm{~g} / \mathrm{L}$ throughout the experiment. The inlet $\mathrm{pH}$ was continuously monitored and was $7.56 \pm 0.2$.

The experimental investigation of the dynamic response of the activated sludge process bioreactor was conducted using conductivity measurement of a sodium chloride solution (10 g/L), which was constantly fed to the aeration tank from the inlet tank.

To conduct a blank experiment without activated sludge, all reactor units were filled completely with the synthetic wastewater. The wastewater composition was the same as in the acclimatization stage. The same operating conditions were used as in the rest of the experiments. The blank experiment lasted 6 days.

The first stage of the experiment with activated sludge was conducted without emerging pollutants. Then, the three stages included addition of caffeine $(30 \mathrm{mg} / \mathrm{L})$, metronidazole (30 $\mathrm{mg} / \mathrm{L})$ and ibuprofen $(30 \mathrm{mg} / \mathrm{L})$, separately. The final stage of the experiment was carried out with a mixture of caffeine, metronidazole and ibuprofen with concentrations $10 \mathrm{mg} / \mathrm{L}, 10 \mathrm{mg} / \mathrm{L}$ and 10 
$\mathrm{mg} / \mathrm{L}$, respectively. The addition of the emerging pollutants was done keeping constant the total initial carbon by removing glucose.

A volume of $5 \mathrm{~L}$ of activated sludge sample was obtained from the local Municipal WWTP (Astana Su Arnasy, Nur-Sultan, Kazakhstan). Initially, 26 days were allocated to acclimatize the activated sludge and to reach steady-state in the reactor. Each study stage with the emerging pollutants lasted 10 days and samples were withdrawn periodically and sent for analysis. Following the 10-days experiment, the reactor was operated with the synthetic wastewater without emerging pollutants for 3 days in order to eliminate their concentration into the system.

\subsection{Analytical methods}

Samples were filtered using the Chromofil Xtra RC-20/25 syringe filters $(0.20 \mu \mathrm{m})$, and diluted with ultra-pure water before the HPLC, Ion Chromatography (IC), TC and TN analysis. Multi N/C 3100 analyzer (Analytik Jena AG, Germany) was used to determine the TC and TN concentrations. Caffeine, ibuprofen and metronidazole were quantified using the Agilent 1290 Infinity HPLC, USA. The concentrations of ammonium and nitrates were determined using the Thermo Scientific Dionex ICS-6000, USA. The details of HPLC, IC, TC and TN analyses are presented in Tables 3, 4 and 5, respectively.

\section{Table 3.}

Table 4.

Table 5 .

The $\mathrm{pH}$, conductivity and DO were measured by WTW inoLab 9310 IDS, Germany. The samples for TSS determination were sampled twice and filtered through vacuum pump using 1.2 $\mu \mathrm{m} \mathrm{GF/F} \mathrm{glass} \mathrm{microfiber} \mathrm{filters.}$ 
The removal of emerging pollutants (EP) and the TC and TN removal as result of the $\mathrm{CO}_{2}$ and $\mathrm{N}_{2}$ production were calculated using the following equations:

$$
\begin{gathered}
\text { EP removal }(\%)=\frac{C_{\text {inlet }}-C_{\text {outlet }}}{C_{\text {inlet }}}, \\
T C \text { removal }(\%)=\frac{[T C]_{\text {inlet }}-[T C]_{\text {outlet }}}{[T C]_{\text {inlet }}}, \\
T N \text { removal }(\%)=\frac{[T N]_{\text {inlet }}-[T N]_{\text {outlet }}}{[T N]_{\text {inlet }}},
\end{gathered}
$$

\section{Results}

\subsection{Blank and tracing experiments}

The blank experiment was conducted with the synthetic wastewater without the activated sludge. The TC and TN removal efficiency during control experiment is shown in Figure 2.

Figure 2.

During the blank experiment, a maximum of $45 \% \mathrm{TC}$ removal and $22 \% \mathrm{TN}$ removal was observed. The average TC and TN concentrations were $264.8 \pm 31.1 \mathrm{mg} / \mathrm{L}$ and $26.4 \pm 2.0 \mathrm{mg} / \mathrm{L}$ in the influent and $158.4 \pm 40.6 \mathrm{mg} / \mathrm{L}$ and $20.5 \pm 0.9 \mathrm{mg} / \mathrm{L}$ in the effluent. The relatively high $\mathrm{TC}$ removal values are mainly due to the bacterial contamination in the tank with the synthetic wastewater and in less extent related to evaporation due to aeration.

Very limited number of works in the literature include blank experiments using activated sludge bioreactors. ${ }^{47}$ used SBR for the treatment of palm oil mill effluent and achieved average COD removal of $35 \%$ in 40 days and linked this removal with foaming. On contrary, ${ }^{48}$ reported that TC concentration remained almost unchanged after $72 \mathrm{~h}$ of blank experiment without nitrifying sludge, eliminating the contribution of hydrolysis and volatilization of TC. 
In a recent study with the similar synthetic wastewater, ${ }^{46}$ evaluated the influence of the air striping by using sequential batch reactor (SBR), and after 21 hours of intensive aeration they reported $43.9 \%$ TC removal, and $29.4 \%$ and $10.5 \%$ removal of the 2 -chlorophenol and 2,4,6trichlorophenol, respectively. According to the literature, Henry solubility $\left(\mathrm{H}_{\mathrm{cp}}\right)$ values for compounds used are as follows: caffeine $9.0 \times 10^{5} \mathrm{~mol} /\left(\mathrm{m}^{3} \times \mathrm{Pa}\right)$, ibuprofen $6.6 \times 10^{1} \mathrm{~mol} /\left(\mathrm{m}^{3} \times \mathrm{Pa}\right)$, metronidazole $5.8 \times 10^{5} \mathrm{~mol} /\left(\mathrm{m}^{3} \times \mathrm{Pa}\right), \quad$ 2-chlorophenol $8.8 \times 10^{-1} \mathrm{~mol} /\left(\mathrm{m}^{3} \times \mathrm{Pa}\right)$ and $2,4,6$ trichlorophenol $3.8 \mathrm{~mol} /\left(\mathrm{m}^{3} \times \mathrm{Pa}\right){ }^{49}$. Since the volatility of caffeine, ibuprofen and metronidazole are considerably less than these of chlorophenols, it should be concluded that the emerging pollutants used in the current work were relatively resistant to stripping and it was unlikely to have a significant loss of them due to evaporation.

Step input change experiment was conducted to study the hydrodynamic behavior of the bioreactor. The results of the tracer studies are shown in Figure 3.

Figure 3.

The activated sludge bioreactor essentially behaved as a continuous stirred-tank reactor (CSTR) vessel. The experimental residence time in the aeration tank was $25.6 \mathrm{~h}$ compared to 25.5 $\mathrm{h}$ of the theoretical residence time. From the experimental cumulative distribution function, it was found that the reactor reached $94 \%$ of the inlet concentration after $72 \mathrm{~h}$ and practically entered steady state operation, which justified the use of a 10-days experiment with the emerging pollutants with additional 3-days operation with the synthetic wastewater without any emerging pollutant after each run.

\subsection{TC and TN removal}


During the acclimatization period, significant TC and TN removal and efficient suspended solids concentration were achieved in the activated sludge bioreactor (Figure 4). Specifically, the average percentage removal of TC and TN were $79.7 \pm 9.3 \%$ and $64.2 \pm 16.3 \%$, respectively. The average TC and TN concentrations were $221.0 \pm 55.7 \mathrm{mg} / \mathrm{L}$ and $24.1 \pm 4.2 \mathrm{mg} / \mathrm{L}$ in the influent and $43.6 \pm 15.8 \mathrm{mg} / \mathrm{L}$ and $10.1 \pm 4.3 \mathrm{mg} / \mathrm{L}$ in the effluent.

Figure 4.

The average concentration of total suspended solids (TSS) in both anoxic and aerobic reactors was higher than $1.5 \mathrm{~g} / \mathrm{L}$ in all stages of the experiment (Table 6).

Table 6.

In Stage B, the average TC and TN concentrations were $264.9 \pm 55.2 \mathrm{mg} / \mathrm{L}$ and $33.9 \pm 3.8 \mathrm{mg} / \mathrm{L}$ in the influent, and $47.3 \pm 10.6 \mathrm{mg} / \mathrm{L}$ and $18.5 \pm 1.9 \mathrm{mg} / \mathrm{L}$ in the effluent. No increase in TC removal efficiency in the activated sludge bioreactor was observed after the addition of $30 \mathrm{mg} / \mathrm{L}$ caffeine to the raw synthetic wastewater (Table 6). However, the TN removal efficiency experienced a sharp decrease down to $46 \%$, which could be probably explained by the inhibitory effect of caffeine on ammonia-oxidizing bacteria ${ }^{22}$. In addition, the average concentration of TSS showed a small increase as caffeine has the capability to enhance the biomass production of some microorganisms ${ }^{50}$.

In Stage C, the average TC and TN concentrations were $279.2 \pm 18.2 \mathrm{mg} / \mathrm{L}$ and $32.7 \pm 2.7 \mathrm{mg} / \mathrm{L}$ in the influent, and $72.9 \pm 17.0 \mathrm{mg} / \mathrm{L}$ and $21.2 \pm 0.7 \mathrm{mg} / \mathrm{L}$ in the effluent. Over the duration of the Stage $\mathrm{C}$, no significant reduction in the TC removal efficiency was noticed in the activated sludge bioreactor, while the TN removal declined twice in comparison with Stage A, where emerging pollutants were not present (Table 6). This was expected as metronidazole is antibiotic and a 
recalcitrant compound. It can adversely affect the bacterial growth and it was reported that $2 \mathrm{mM}$ concentration of metronidazole six fold suppressed the growth rate of denitrifying bacteria ${ }^{51}$.

As the efficiency of the process was considerably affected by metronidazole during Stage C, a 24-days period of time (Stage A2) was allocated to wash out the antibiotic from the system and to give it time to recover. This resulted in an increase of the $\mathrm{TC}$ and $\mathrm{TN}$ removal to $76 \%$ and $61 \%$, respectively. As with Stage $\mathrm{C}$, the addition of $30 \mathrm{mg} / \mathrm{L}$ ibuprofen to the influent wastewater resulted in the sharp drop of the average TN removal efficiency down to $41 \%$ (Figure 4 ). In addition, the average TC removal efficiency was also affected and decreased to $60 \%$ (Table 6 ). In Stage D, the average TC and TN concentrations were $262.2 \pm 26.1 \mathrm{mg} / \mathrm{L}$ and $27.5 \pm 3.2 \mathrm{mg} / \mathrm{L}$ in the influent, and $103.3 \pm 10.1 \mathrm{mg} / \mathrm{L}$ and $15.7 \pm 2.1 \mathrm{mg} / \mathrm{L}$ in the effluent. These results are in agreement with the literature, where the activity of aerobic microorganisms in activated sludge was reported to be substantially inhibited at high concentrations $(0.5$ and $1 \mathrm{~g} / \mathrm{L})$ of ibuprofen ${ }^{40}$.

Finally, the effect of the combination of the three emerging pollutants on the performance of activated sludge process was studied using $10 \mathrm{mg} / \mathrm{L}$ for each compound. In Stage E, the average TC and TN concentrations were $242.4 \pm 35.2 \mathrm{mg} / \mathrm{L}$ and $32.6 \pm 2.6 \mathrm{mg} / \mathrm{L}$ in the influent, and $77.5 \pm 20.0 \mathrm{mg} / \mathrm{L}$ and $21.8 \pm 4.0 \mathrm{mg} / \mathrm{L}$ in the effluent. In this case, both average TC and TN removal efficiencies decreased to $68 \%$ and $32 \%$, respectively (Table 6). As it has been already noted, when treated separately all of the three compounds inhibited the TN removal efficiency. Consequently, combination of caffeine, metronidazole and ibuprofen harshly affected the TN removal efficiency, decreasing it to $22 \%$ at the $10^{\text {th }}$ day of the Stage E. As it can be seen in Table 6 , the average TC removal efficiency ranged from $60 \%$ to $82 \%$. This range was maintained during the study as a result of the versatility of the reactor operating at high sludge retentions time (SRT), which enabled the operation to avoid washouts and retain adequate TSS concentration. 


\subsection{Nitrification and denitrificafion}

Biological nitrification is the process where ammonium ions are oxidized or converted into nitrite ions and then to nitrate ions. During nitrification, two energy-yielding biochemical reactions occur. More energy is obtained from the oxidation of ammonium ions than the oxidation of nitrite ions (Equations 4 and 5):

$$
\begin{gathered}
\mathrm{NH}_{4}^{+}+1.5 \mathrm{O}_{2} \rightarrow \mathrm{NO}_{2}^{-}+2 \mathrm{H}^{+}+\mathrm{H}_{2} \mathrm{O}, \\
\mathrm{NO}_{2}^{-}+0.5 \mathrm{O}_{2} \rightarrow \mathrm{NO}_{3}^{-} .
\end{gathered}
$$

The ammonium ions are generally oxidized to nitrites by nitrifying bacteria of genera Nitrosococcus, Nitrosocystis, Nitrosolobus, Nitrosomonas and Nitrosospira, while nitrites are converted to nitrates by Nitrobacter, Nitrococcus and Nitrospira ${ }^{52-54}$.

Biological denitrification is the degradation of organic-carbon containing compounds (cBOD) using the nitrite ions or nitrate ions by denitrifying bacteria (facultative anaerobes). The vast majority of denitrifying bacteria are from the genera Alcaligenes, Bacillus and Pseudomonas ${ }^{53}$. Denitrification is stepwise process and occurs inside the bacterial cell where nitrite and nitrate ions are reduced to molecular nitrogen. The overall degradation process can be expressed in two simplified reactions (Equations 6 and 7):

$$
\begin{gathered}
\mathrm{NO}_{3}{ }^{-}+\mathrm{cBOD} \rightarrow \mathrm{NO}_{2}{ }^{-}+\mathrm{CO}_{2}+\mathrm{H}_{2} \mathrm{O}, \\
\mathrm{NO}_{2}{ }^{-}+\mathrm{cBOD} \rightarrow \mathrm{N}_{2}+\mathrm{CO}_{2}+\mathrm{H}_{2} \mathrm{O} .
\end{gathered}
$$

The energy yield of these reactions is lower than in the nitrification process and it is crucial to maintain anoxic conditions (DO less than $1 \mathrm{mg} / \mathrm{L}$ ) as facultative anaerobes can switch to aerobic respiration. 
Several studies have evaluated how caffeine, metronidazole and ibuprofen affect the biological activity of microorganisms ${ }^{22,40,51,55}$. As pointed out by ${ }^{55}$, caffeine, ibuprofen and their degradation/transformation products produce toxic effect in riverine microbial communities by suppressing cyanobacteria. It has been also reported by several research groups ibuprofen inhibits the activity of aerobic heterotrophic bacteria such as Candidatus Competibacter while metronidazole suppresses the activity of denitrifying bacteria like Rhodobacter sphaeroides ${ }^{40,51}$.

The removal performance of $\mathrm{NH}_{4}{ }^{+}-\mathrm{N}$ and $\mathrm{NO}_{3}{ }^{-}-\mathrm{N}$ is shown in Figures 5 and 6 .

Figure 5.

Figure 6.

Initially, efficient nitrification and denitrification processes were established during Stage A. The TN removal efficiency was inhibited in all stages with emerging pollutants and this seems to be caused by different reasons for each of them. As it is shown in Figure 5, in the presence of caffeine, the $\mathrm{NH}_{4}{ }^{+}-\mathrm{N}$ concentration in the effluent increased from 0 to $8.9 \mathrm{mg} / \mathrm{L}$ at the end of Stage B, which can be explained by the suppression of biological activity of microorganisms in the nitrification zone ${ }^{22}$. The concentration of $\mathrm{NO}_{3}{ }^{-}-\mathrm{N}$ fluctuated between 1 to $3 \mathrm{mg} / \mathrm{L}$ in the effluent (Figure 6).

In the case of metronidazole, the $\mathrm{NH}_{4}{ }^{+}-\mathrm{N}$ concentration in the effluent ranged in $1.8-1.5$ $\mathrm{mg} / \mathrm{L}$. The concentration of $\mathrm{NO}_{3}{ }^{-}-\mathrm{N}$ in the effluent was sharply increased from 2.4 to $13 \mathrm{mg} / \mathrm{L}$. These results indicate that metronidazole suppressed the activity of the respective heterotrophs (denitrification) and autotrophs (nitrification), which is in agreement with the literature ${ }^{51}$. It was reported by ${ }^{51}$ that metronidazole inhibited the bacterial growth decreasing the specific growth rate, affecting the lag phase duration and delaying the decrease of redox potential. As it can be seen from Figure S.2, the DO of denitrification zone (anoxic part) of the reactor, which is 
responsible for reduction of $\mathrm{NO}_{3}{ }^{-}$, was effectively zero throughout the experiment. Moreover, the increase of nitrates was observed only in cases when metronidazole was present in the system. Due to the low molecular weight, metronidazole easily penetrates the cell membrane of both anaerobes and aerobes and reactive intermediates formed by the reduction of metronidazole damage the DNA of the microorganisms. It was noted that ferri-doxin system, that mediates the reductive process of metronidazole, present in anaerobes, which explains the selective effect of metronidazole against anaerobic microorganisms ${ }^{56}$. Therefore, the presence of metronidazole is highly likely to affect primarily the denitrification and increase the concentration of nitrates in the system.

After metronidazole input was stopped, the nitrate nitrogen and ammonium nitrogen in the effluent dropped to the less than $0.1 \mathrm{mg} / \mathrm{L}$, which is a normal operation of activated sludge process (Stage A2). During Stage D, it is clearly seen from Figure 5 that the concentration of ammonium nitrogen sharply rises to $13.1 \mathrm{mg} / \mathrm{L}$, which averages that ibuprofen considerably affected the nitrification process. As the nitrates production stopped, it is not clear if ibuprofen also affects the activity of denitrifying microbiota. Based on literature ibuprofen inhibits the activity of ammonium and nitrite oxidizing bacteria which is in agreement with the findings of the present study ${ }^{40}$.

Finally, caffeine, ibuprofen and metronidazole were studied in combination at a concentration of $10 \mathrm{mg} / \mathrm{L}$ each. According to Figure 5, the concentration of $\mathrm{NH}_{4}{ }^{+}-\mathrm{N}$ in the effluent decreased from 14.2 to $0.9 \mathrm{mg} / \mathrm{L}$ over the period of Stage E. This indicates that there was no inhibition of nitrifying autotrophs, probably due to the lower concentration of caffeine and ibuprofen. Another explanation could be that the microbial composition of activated sludge shifted and gained resistance against these compounds ${ }^{57}$. On the other hand, it can be seen in Figure 6 that the concentration of nitrate nitrogen in the effluent increased sharply from 1.2 to $21.5 \mathrm{mg} / \mathrm{L}$, which could be attributed to the presence of metronidazole. As it was mentioned before, the presence of 
metronidazole affected considerably the denitrifying bacteria. Moreover, the concentration of the $\mathrm{NO}_{3}{ }^{-}-\mathrm{N}$ in the effluent was higher than the concentration of $\mathrm{NH}_{4}{ }^{+}-\mathrm{N}$ in the influent. This excess amount of nitrogen was likely due to the deamination process, where the amino group was released from amino acids and proteins, and quickly converted to the ammonium ion. This reaction occurs in the presence of the hydrogen ions (Equation 8) ${ }^{53}$ :

$$
\mathrm{NH}_{2}+2 \mathrm{H}^{+} \rightarrow \mathrm{NH}_{4}^{+} \text {. }
$$

As demonstrated by nitrification/denitrification tests, it is important to remove caffeine, metronidazole and ibuprofen before the biological treatment of wastewater in order to avoid disturbance in the TN removal efficiency.

\subsection{Fate of emerging pollutants in the activated sludge process}

The average concentration of emerging pollutants in influent wastewater were $28.11 \pm 0.49$ $\mathrm{mg} / \mathrm{L}$ for caffeine (Stage B), 26.28 $\pm 0.44 \mathrm{mg} / \mathrm{L}$ for metronidazole (Stage C), $26.67 \pm 1.19 \mathrm{mg} / \mathrm{L}$ for ibuprofen (Stage D), and 10.55 $\pm 0.15 \mathrm{mg} / \mathrm{L}, 9.36 \pm 0.15 \mathrm{mg} / \mathrm{L}$ and $10.34 \pm 0.31 \mathrm{mg} / \mathrm{L}$ for caffeine, metronidazole and ibuprofen combined, respectively (Stage E). Caffeine and ibuprofen were completely removed, while metronidazole was resistant to biological degradation (Table 7).

\section{Table 7.}

The average removal of caffeine in Stage B was $99.03 \pm 0.70 \%$, which shows that it was completely biodegradable. This result correlates well with the literature, where a complete removal of caffeine was observed when the activated sludge process was used ${ }^{58}$. In the work of ${ }^{59}$, compost leachate was treated using a membrane bioreactor. They achieved 99.9\% removal of caffeine with initial concentration of $1.33 \mathrm{mg} / \mathrm{L}$, and reported that the high removal efficiency of caffeine is 
linked to its biodegradation or biotransformation by microorganisms. In addition, caffeine can be used as a sole substrate for microbial methane production. ${ }^{14}$ confirmed an $87.5 \%$ removal of caffeine with initial concentration of $470 \mathrm{mg} / \mathrm{L}$ from the coffee processing wastewater using anaerobic membrane bioreactor in a continuous operation and converted caffeine to methane successfully.

In Stage C, the removal of metronidazole is between 12 and 27\%. The low removal percentage of metronidazole is possibly linked to the antibiotic inhibition of the microorganisms present in the activated sludge ${ }^{26}$. Metronidazole has stable and highly polar imidazole ring which makes it highly soluble in water $(9.5 \mathrm{~g} / \mathrm{L})^{60}$. Imidazoles are strong bactericides and inhibit the biosynthesis of nucleic acid of microorganisms. In addition to anaerobes, they are also mutagenic to fungi and rodents ${ }^{56}$. Similar results on metronidazole removal with activated sludge was obtained by ${ }^{61}(15 \%$ after 10 days), and ${ }^{24}$ (22\% after 9 days), while ${ }^{42}$ achieved more than $80 \%$ removal of metronidazole using a combined anoxic/anaerobic reactor. These differences can be explained by the variation of microbial community of the activated sludge and other parameters like retention time and sludge age used in the activated sludge process. The recalcitrance of metronidazole is linked to the high stability of imidazole ring which has a two nitrogen atoms in the aromatic ring 23. Biological removal of metronidazole is correlated with the production of the exopolymeric substances, which plays major role in the adsorption of this compound. However, high concentration of metronidazole limits the biodegradation capacity of the microorganisms ${ }^{27}$.

Complete removal of ibuprofen with concentration of $30 \mathrm{mg} / \mathrm{L}$ was observed during Stage D. Ibuprofen is readily biodegradable and its removal up to $99 \%$ at concentration of $10 \mu \mathrm{g} / \mathrm{L}$ was accomplished even at $12^{\circ} \mathrm{C}$ in 24 hours ${ }^{30}$. Other studies on the impact of high concentration of ibuprofen found that in concentrations of $50 \mathrm{mg} / \mathrm{L}$ and above ibuprofen inhibits the microbial 
activity of activated sludge. Moreover, in the presence of $1000 \mathrm{mg} / \mathrm{L}$ of ibuprofen substantial changes in microbial composition of activated sludge and increased occurrence of antibioticresistant bacteria of genera Enterobacteriales has been observed ${ }^{57}$.

Finally, in Stage E both biodegradable compounds caffeine and ibuprofen at concentration were completely removed. The average removal efficiency of metronidazole was $53.4 \pm 2.18 \%$. This increase in removal rate can be explained by the reduction of its concentration. Additionally, the presence of ibuprofen in bioreactor during the Stage D might have increased the number of antibiotic-resistant bacteria, which could possibly increase the microbial activity of activated sludge ${ }^{57}$.

\section{Conclusions}

This work evaluated the biodegradability and inhibitory characteristics of caffeine, metronidazole and ibuprofen, which are commercial drugs frequently found in wastewater effluents. A synthetic wastewater was prepared and treated in a continuous flow conventional activated sludge process operating for 95 days. The main results are:

1) During the separate treatment, the removal was $99.03 \pm 0.70 \%$ for caffeine, $100 \%$ for ibuprofen and $17.34 \pm 7.14 \%$ for metronidazole. When treated in combination, the removal efficiencies observed were $100 \%, 53.4 \pm 2.18 \%$ and $94.59 \pm 7.65 \%$ for caffeine, metronidazole, and ibuprofen, respectively.

2) It has been found that the presence of ibuprofen $(30 \mathrm{mg} / \mathrm{L})$ and metronidazole $(30 \mathrm{mg} / \mathrm{L})$ decreased the TC removal efficiency, while the addition of caffeine $(30 \mathrm{mg} / \mathrm{L})$ had no effect on the TC removal efficiency. On the contrary, the TN removal efficiency declined at all experimental stages with emerging pollutants. 
3) From the IC results, it has been observed that the presence of caffeine $(30 \mathrm{mg} / \mathrm{L})$ and ibuprofen $(30 \mathrm{mg} / \mathrm{L})$ affected the nitrification, while metronidazole $(30 \mathrm{mg} / \mathrm{L})$ inhibited the denitrification process.

4) The cumulative presence of caffeine, metronidazole and ibuprofen in the synthetic wastewater resulted in poor $\mathrm{TC}(68 \%)$ and $\mathrm{TN}(32 \%)$ removal efficiencies. It was found that the combination of emerging pollutants deteriorated the denitrification process, resulting in the presence of unconverted $\mathrm{NO}_{3}{ }^{-}$ions in the effluent.

\section{ACKNOWLEDGMENTS}

This work was financially supported by the Nazarbayev University project "Development of a Novel Technology for Production of High Quality Reclaimed Water: Track Etch Membrane Bioreactor", Faculty Development Competitive Research Grants Program for 2019-2021, Grant Number: 110119FD4533 awarded to Dr. E. Arkhangelsky. The authors gratefully acknowledge the assistance of Mr. Zhanpeis Issayev for the analysis of $\mathrm{NO}_{3}{ }^{-}$and $\mathrm{NH}_{4}{ }^{+}$on ion chromatography. The technical support of Core Facilities of Nazarbayev University is greatly acknowledged.

\section{REFERENCES}

1. Sauvé S, Desrosiers M. A review of what is an emerging contaminant. Chem Cent $J \mathbf{8}(\mathbf{1})$, 1-7 (2014).

2. Martínez-Alcalá I, Guillén-Navarro JM, Fernández-López C. Pharmaceutical biological degradation, sorption and mass balance determination in a conventional activated-sludge wastewater treatment plant from Murcia, Spain. Chem Eng J 316, 332-340 (2017). http://dx.doi.org/10.1016/j.cej.2017.01.048

3. Gurung K, Ncibi MC, Sillanpää M. Removal and fate of emerging organic micropollutants (EOMs) in municipal wastewater by a pilot-scale membrane bioreactor (MBR) treatment under varying solid retention times. Sci Total Environ 667, 671-680 (2019). https://doi.org/10.1016/j.scitotenv.2019.02.308

4. Ahmed MB, Zhou JL, Ngo HH, Guo W, Thomaidis NS, Xu J. Progress in the biological and chemical treatment technologies for emerging contaminant removal from wastewater: A critical review. J Hazard Mater 323, 274-298 (2017). 
http://dx.doi.org/10.1016/j.jhazmat.2016.04.045

5. Dvořáková Březinova T, Vymazal J, Koželuh M, Kule L. Occurrence and removal of ibuprofen and its metabolites in full-scale constructed wetlands treating municipal wastewater. Ecol Eng, 120(May), 1-5 (2018).

6. Köhler C, Venditti S, Igos E, Klepiszewski K, Benetto E, Cornelissen A. Elimination of pharmaceutical residues in biologically pre-treated hospital wastewater using advanced UV irradiation technology: A comparative assessment. J Hazard Mater 239-240, 70-77 (2012). http://dx.doi.org/10.1016/j.jhazmat.2012.06.006

7. Monsalvo VM, Lopez J, Munoz M, de Pedro ZM, Casas JA, Mohedano AF, et al. Application of Fenton-like oxidation as pre-treatment for carbamazepine biodegradation. Chem Eng J 264, 856-862 (2015). http://dx.doi.org/10.1016/j.cej.2014.11.141

8. Merayo N, Hermosilla D, Blanco L, Cortijo L, Blanco Á. Assessing the application of advanced oxidation processes, and their combination with biological treatment, to effluents from pulp and paper industry. J Hazard Mater 262, 420-427 (2013).

9. Kozlovskiy A, Zdorovets M, Arkhangelsky E. Track-etch membranes: The Kazakh experience. Desalin Water Treat 76, 143-147 (2017).

10. Poulopoulos SG, Yerkinova A, Ulykbanova G, Inglezakis VJ. Photocatalytic treatment of organic pollutants in a synthetic wastewater using UV light and combinations of $\mathrm{TiO} 2$, $\mathrm{H} 2 \mathrm{O} 2$ and $\mathrm{Fe}(\mathrm{III})$. PLoS One 14(5), 1-20 (2019).

11. Osachoff HL, Mohammadali M, Skirrow RC, Hall ER, Brown LLY, van Aggelen GC, et al. Evaluating the treatment of a synthetic wastewater containing a pharmaceutical and personal care product chemical cocktail: Compound removal efficiency and effects on juvenile rainbow trout. Water Res 62, 271-280 (2014). http://dx.doi.org/10.1016/j.watres.2014.05.057

12. Klavarioti M, Mantzavinos D, Kassinos D. Removal of residual pharmaceuticals from aqueous systems by advanced oxidation processes. Environment International, 402-417 (2009).

13. Sui Q, Cao X, Lu S, Zhao W, Qiu Z, Yu G. Occurrence, sources and fate of pharmaceuticals and personal care products in the groundwater: A review. Emerg Contam 1(1), 14-24 (2015). http://dx.doi.org/10.1016/j.emcon.2015.07.001

14. Chen R, Jiang H, Li YY. Caffeine degradation by methanogenesis: Efficiency in anaerobic membrane bioreactor and analysis of kinetic behavior. Chem Eng J 334, 444 452 (2018).

15. Mazzafera P. Degradaç ão de cafeína por microrganismos e o emprego da palha e polpa de café descafeinados na alimentaç ão animal. Sci Agric 59(4), 815-821 (2002).

16. Nanjundaiah S, Mutturi S, Bhatt P. Modeling of caffeine degradation kinetics during cultivation of Fusarium solani using sucrose as co-substrate. Biochem Eng J 125, 73-80. http://dx.doi.org/10.1016/j.bej.2017.05.018

17. Asano Y, Yamada H, Komeda T. Enzymes Involved in Theobromine Production from Caffeine by Pseudomonas putida No. 352. Biosci Biotechnol Biochem 58(12), 2303-2304 (1994).

18. Hakil M, Denis S, Viniegra-González G, Augur C. Degradation and product analysis of caffeine and related dimethylxanthines by filamentous fungi. Enzyme Microb Technol 22(5), 355-359 (1998).

19. Mohapatra BR, Harris N, Nordin R, Mazumder A. Purification and characterization of a novel caffeine oxidase from Alcaligenes species. J Biotechnol 125(3), 319-327 (2006). 
20. Shreve MJ, Brennan RA. Trace organic contaminant removal in six full-scale integrated fixed-film activated sludge (IFAS) systems treating municipal wastewater. Water Res 151, 318-331 (2019). https://doi.org/10.1016/j.watres.2018.12.042

21. Park J, Yamashita N, Park C, Shimono T, Takeuchi DM, Tanaka H. Removal characteristics of pharmaceuticals and personal care products: Comparison between membrane bioreactor and various biological treatment processes. Chemosphere 179, 347358 (2017). http://dx.doi.org/10.1016/j.chemosphere.2017.03.135

22. Chtourou M, Mallek M, Dalmau M, Mamo J, Santos-Clotas E, Salah A Ben, et al. Triclosan, carbamazepine and caffeine removal by activated sludge system focusing on membrane bioreactor. Process Saf Environ Prot 118, 1-9 (2018) https://doi.org/10.1016/j.psep.2018.06.019

23. Aboudalle A, Fourcade F, Assadi AA, Domergue L, Djelal H, Lendormi T, et al. Reactive oxygen and iron species monitoring to investigate the electro-Fenton performances.

Impact of the electrochemical process on the biodegradability of metronidazole and its byproducts. Chemosphere 199, 486-494 (2018).

https://doi.org/10.1016/j.chemosphere.2018.02.075

24. Aboudalle A, Djelal H, Fourcade F, Domergue L, Assadi AA, Lendormi T, et al. Metronidazole removal by means of a combined system coupling an electro-Fenton process and a conventional biological treatment: By-products monitoring and performance enhancement. J Hazard Mater 359(March), 85-95 (2018).

https://doi.org/10.1016/j.jhazmat.2018.07.006

25. Verlicchi P, Galletti A, Petrovic M, Barceló D, Al Aukidy M, Zambello E. Removal of selected pharmaceuticals from domestic wastewater in an activated sludge system followed by a horizontal subsurface flow bed - Analysis of their respective contributions. Sci Total Environ 454-455, 411-425 (2013). http://dx.doi.org/10.1016/j.scitotenv.2013.03.044

26. Halling-Sørensen B. Inhibition of aerobic growth and nitrification of bacteria in sewage sludge by antibacterial agents. Arch Environ Contam Toxicol 40(4), 451-460 (2001).

27. Hena S, Gutierrez L, Croué JP. Removal of metronidazole from aqueous media by C. vulgaris. J Hazard Mater 384, 121400 (2019)

28. Alamgir, Talha K, Wang B, Liu JH, Ullah R, Feng F, et al. Effective adsorption of metronidazole antibiotic from water with a stable $\mathrm{Zr}(\mathrm{IV})-\mathrm{MOF}$ : Insights from DFT, kinetics and thermodynamics studies. J Environ Chem Eng 8(1), 103642 (2020). https://doi.org/10.1016/j.jece.2019.103642

29. Tetorou A, Makhatova A, Poulopoulos SG. Photochemical mineralization of Ibuprofen medicinal product by means of UV, hydrogen peroxide, titanium dioxide and Iron. Water Sci Technol 80(11), 2200-2205 (2020). https://doi.org/10.2166/wst.2020.041

30. Kruglova A, Ahlgren P, Korhonen N, Rantanen P, Mikola A, Vahala R. Biodegradation of ibuprofen, diclofenac and carbamazepine in nitrifying activated sludge under $12^{\circ} \mathrm{C}$ temperature conditions. Sci Total Environ 499(1), 394-401 (2014). http://dx.doi.org/10.1016/j.scitotenv.2014.08.069

31. Bernhard M, Müller J, Knepper TP. Biodegradation of persistent polar pollutants in wastewater: Comparison of an optimised lab-scale membrane bioreactor and activated sludge treatment. Water Res 40(18), 3419-3428 (2006).

32. Han S, Choi K, Kim J, Ji K, Kim S, Ahn B, et al. Endocrine disruption and consequences of chronic exposure to ibuprofen in Japanese medaka (Oryzias latipes) and freshwater 
cladocerans Daphnia magna and Moina macrocopa. Aquat Toxicol 98(3), 256-264 (2010).

33. Jiménez-Silva VA, Santoyo-Tepole F, Ruiz-Ordaz N, Galíndez-Mayer J. Study of the ibuprofen impact on wastewater treatment mini-plants with bioaugmented sludge. Process Saf Environ Prot 123, 140-149 (2019). https://doi.org/10.1016/j.psep.2018.08.006

34. Quintelas C, Mesquita DP, Torres AM, Costa I, Ferreira EC. Degradation of widespread pharmaceuticals by activated sludge: Kinetic study, toxicity assessment, and comparison with adsorption processes. J Water Process Eng 33, 101061 (2020). https://doi.org/10.1016/j.jwpe.2019.101061

35. Maeng SK, Choi BG, Lee KT, Song KG. Influences of solid retention time, nitrification and microbial activity on the attenuation of pharmaceuticals and estrogens in membrane bioreactors. Water Res 47(9), 3151-3162 (2013).

http://dx.doi.org/10.1016/j.watres.2013.03.014

36. Matongo S, Birungi G, Moodley B, Ndungu P. Pharmaceutical residues in water and sediment of Msunduzi River, KwaZulu-Natal, South Africa. Chemosphere 134, 133-140 (2015). http://dx.doi.org/10.1016/j.chemosphere.2015.03.093

37. Afonso-Olivares C, Fernández-Rodríguez C, Ojeda-González RJ, Sosa-Ferrera Z, Santana-Rodríguez JJ, Rodríguez JMD. Estimation of kinetic parameters and UV doses necessary to remove twenty-three pharmaceuticals from pre-treated urban wastewater by UV/H2O2. J Photochem Photobiol A Chem 329, 130-138 (2016). http://dx.doi.org/10.1016/j.jphotochem.2016.06.018

38. Ajo P, Preis S, Vornamo T, Mänttäri M, Kallioinen M, Louhi-Kultanen M. Hospital wastewater treatment with pilot-scale pulsed corona discharge for removal of pharmaceutical residues. J Environ Chem Eng 6(2), 1569-1577 (2018). https://doi.org/10.1016/j.jece.2018.02.007

39. Xia Y, Zhang Q, Li G, Tu X, Zhou Y, Hu X. Biodegradability enhancement of real antibiotic metronidazole wastewater by a modified electrochemical Fenton. J Taiwan Inst Chem Eng 96, 256-263 (2019). https://doi.org/10.1016/j.jtice.2018.11.019

40. Jia Y, Yin L, Khanal SK, Zhang H, Oberoi AS, Lu H. Biotransformation of ibuprofen in biological sludge systems: Investigation of performance and mechanisms. Water Res 170, 115303 (2020). https://doi.org/10.1016/j.watres.2019.115303

41. Sun $\mathrm{H}$, Wang $\mathrm{T}$, Yang Z, Yu C, Wu W. Simultaneous removal of nitrogen and pharmaceutical and personal care products from the effluent of waste water treatment plants using aerated solid-phase denitrification system. Bioresour Technol 287(May), 121389 (2019). https://doi.org/10.1016/j.biortech.2019.121389

42. Phan H V., Hai FI, Kang J, Dam HK, Zhang R, Price WE, et al. Simultaneous nitrification/denitrification and trace organic contaminant (TrOC) removal by an anoxicaerobic membrane bioreactor (MBR). Bioresour Technol 165(1), 96-104 (2014). http://dx.doi.org/10.1016/j.biortech.2014.03.094

43. Zolfaghari M, Drogui P, Seyhi B, Brar SK, Buelna G, Dubé R, et al. Investigation on removal pathways of Di 2-ethyl hexyl phthalate from synthetic municipal wastewater using a submerged membrane bioreactor. J Environ Sci (China) 37, 37-50 (2015). http://dx.doi.org/10.1016/j.jes.2015.03.025

44. Sun J, Wang X, Li R, Zhu WT, Li Y. Hyperhaline municipal wastewater treatment of a processing zone through pilot-scale A/O MBR, part II: Nitrogen and phosphorous removal. Procedia Environ Sci 8(November), 781-788 (2011). http://dx.doi.org/10.1016/j.proenv.2011.10.118 
45. Yerkinova A, Balbayeva G, Inglezakis VJ, Poulopoulos SG. Photocatalytic Treatment of a Synthetic Wastewater. IOP Conf Ser Mater Sci Eng 301(1), (2018).

46. Doskaliyev D, Poulopoulos SG, Yeshmuratov A, Aldyngurova F, Zorpas AA, Inglezakis VJ. Effects of 2-chlorophenol and 2,4,6-trichlorophenol on an activated sludge sequencing batch reactor. Desalin Water Treat 133, 283-291 (2018).

47. Abdullah SA, Majdi NM, Fatin S, Shikh R, Abdullah N, Yuzir A. Sequencing Batch Reactor for Treatment of Palm Oil Mill Effluent. Res J Pharm Biol Chem Sci 5(5), $1242-$ 1249 (2014).

48. Song C, Sun XF, Xia PF, Wang YK, Wang SG. Investigation of fate and behavior of tetracycline in nitrifying sludge system. RSC Adv 5(106), 87333-87340 (2015).

49. U.S. National Library of Medicine. Hazardous Substances Data Bank. Toxnet: Heroin Casrn, 561-27-3, (2015).

50. Nsenga Kumwimba M, Meng F. Roles of ammonia-oxidizing bacteria in improving metabolism and cometabolism of trace organic chemicals in biological wastewater treatment processes: A review. Sci Total Environ 659, 419-441 (2019).

51. Sargsyan H, Gabrielyan L, Trchounian A. Concentration-dependent effects of metronidazole, inhibiting nitrogenase, on hydrogen photoproduction and protontranslocating ATPase activity of Rhodobacter sphaeroides. Int J Hydrogen Energy 39(1), 100-106 (2014).

52. Inglezakis VJ, Amzebek A, Kuspangaliyeva B, Sarbassov Y, Balbayeva G, Yerkinova A, et al. Treatment of municipal solid waste landfill leachate by use of combined biological, physical and photochemical processes. Desalin Water Treat 112, 218-231 (2018).

53. Elmerich C. Nitrification and denitrification in the activated sludge process. Research in Microbiology 153, 253 (2002).

54. Nesseris GK, Stasinakis AS. Investigation of municipal and olive mill wastewater cotreatment in activated sludge-powdered activated carbon (AS-PAC) systems. $J$ Chem Technol Biotechnol 87(4), 540-545 (2012).

55. Lawrence JR, Swerhone GDW, Wassenaar LI, Neu TR. Effects of selected pharmaceuticals on riverine biofilm communities. Can J Microbiol 51(8), 655-669 (2005).

56. Lanzky PF, Halling-Sørensen B. The toxic effect of the antibiotic metronidazole on aquatic organisms. Chemosphere 35(11), 2553-2561 (1997).

57. Davids M, Gudra D, Radovica-Spalvina I, Fridmanis D, Bartkevics V, Muter O. The effects of ibuprofen on activated sludge: Shift in bacterial community structure and resistance to ciprofloxacin. J Hazard Mater 340, 291-299 (2017). http://dx.doi.org/10.1016/j.jhazmat.2017.06.065

58. Majewsky M, Gallé T, Yargeau V, Fischer K. Active heterotrophic biomass and sludge retention time (SRT) as determining factors for biodegradation kinetics of pharmaceuticals in activated sludge. Bioresour Technol 102(16), 7415-7421 (2011).

http://dx.doi.org/10.1016/j.biortech.2011.05.032

59. Brown K, Ghoshdastidar AJ, Hanmore J, Frazee J, Tong AZ. Membrane bioreactor technology: A novel approach to the treatment of compost leachate. Waste Manag 33(11), 2188-2194 (2013). http://dx.doi.org/10.1016/j.wasman.2013.04.006

60. Malakootian M, Kannan K, Gharaghani MA, Dehdarirad A, Nasiri A, Shahamat YD, et al. Removal of metronidazole from wastewater by $\mathrm{Fe} /$ charcoal micro electrolysis fluidized bed reactor. J Environ Chem Eng 7(6), 103457 (2019). 
https://doi.org/10.1016/j.jece.2019.103457

61. Saidi I, Soutrel I, Floner D, Fourcade F, Bellakhal N, Amrane A, et al. Indirect electroreduction as pretreatment to enhance biodegradability of metronidazole. $J$ Hazard Mater 278, 172-179 (2014). http://dx.doi.org/10.1016/j.jhazmat.2014.06.003 
Table 1. Short summary of studies on removal of emerging pollutants using different wastewater treatment techniques

\begin{tabular}{|c|c|c|c|c|}
\hline Method & Target compound & Concentration & $\begin{array}{c}\text { Removal } \\
\text { efficiency, } \\
\% \\
\end{array}$ & Reference \\
\hline $\begin{array}{c}\text { Conventional activated sludge } \\
\text { process }\end{array}$ & Caffeine & $45 \mathrm{ng} / \mathrm{L}$ & 68.6 & 11 \\
\hline $\begin{array}{l}\text { Integrated fixed-film activated sludge } \\
\text { process }\end{array}$ & Caffeine & $670 \mu \mathrm{g} / \mathrm{L}$ & 100 & 20 \\
\hline $\begin{array}{c}\text { Anoxic-aerobic Membrane } \\
\text { Bioreactor }\end{array}$ & Caffeine & $7.4 \mu \mathrm{g} / \mathrm{L}$ & 97 & 21 \\
\hline Anaerobic Membrane Bioreactor & Caffeine & $470 \mathrm{mg} / \mathrm{L}$ & 87.5 & 14 \\
\hline Anoxic Membrane Bioreactor & Caffeine & $1 \mathrm{mg} / \mathrm{L}$ & 97 & 22 \\
\hline Aerobic Membrane Bioreactor & Caffeine & $143 \mu \mathrm{g} / \mathrm{L}$ & 99.9 & 3 \\
\hline $\begin{array}{l}\text { Conventional activated sludge } \\
\text { process }\end{array}$ & Metronidazole & $28 \mathrm{ng} / \mathrm{L}$ & 34 & 25 \\
\hline $\begin{array}{l}\text { Electro-Fenton coupled with } \\
\text { conventional activated sludge process }\end{array}$ & Metronidazole & $100 \mathrm{mg} / \mathrm{L}$ & 89 & 24 \\
\hline Electro-Fenton process & Metronidazole & $100 \mathrm{mg} / \mathrm{L}$ & 100 & 23 \\
\hline Electro-Fenton process & Metronidazole & $1000 \mathrm{mg} / \mathrm{L}$ & 95 & 39 \\
\hline $\begin{array}{c}\text { Conventional activated sludge } \\
\text { process }\end{array}$ & Ibuprofen & $1 \mathrm{mg} / \mathrm{L}$ & 99 & 34 \\
\hline $\begin{array}{l}\text { Conventional activated sludge } \\
\text { process }\end{array}$ & Ibuprofen & $10 \mathrm{mg} / \mathrm{L}$ & 99 & 33 \\
\hline $\begin{array}{c}\text { Activated sludge sequencing batch } \\
\text { reactor }\end{array}$ & Ibuprofen & $20 \mu \mathrm{g} / \mathrm{L}$ & 99 & 30 \\
\hline $\begin{array}{l}\text { Conventional activated sludge } \\
\text { process }\end{array}$ & Ibuprofen & $100 \mu \mathrm{g} / \mathrm{L}$ & 100 & 40 \\
\hline $\begin{array}{c}\text { Conventional activated sludge } \\
\text { process }\end{array}$ & Ibuprofen & $27 \mathrm{ng} / \mathrm{L}$ & 99.5 & 11 \\
\hline $\begin{array}{l}\text { Aerated solid-phase denitrification } \\
\text { system }\end{array}$ & Ibuprofen & $50 \mu \mathrm{g} / \mathrm{L}$ & 79.69 & 41 \\
\hline $\begin{array}{l}\text { Integrated fixed-film activated sludge } \\
\text { system }\end{array}$ & Ibuprofen & $45 \mu \mathrm{g} / \mathrm{L}$ & 100 & 20 \\
\hline Constructed wetlands & Ibuprofen & $14.6 \mu \mathrm{g} / \mathrm{L}$ & 44.7 & 5 \\
\hline $\begin{array}{c}\text { Anoxic-aerobic Membrane } \\
\text { Bioreactor }\end{array}$ & Ibuprofen & $5 \mu \mathrm{g} / \mathrm{L}$ & 94 & 42 \\
\hline Aerobic Membrane Bioreactor & Ibuprofen & $1.02 \mu \mathrm{g} / \mathrm{L}$ & 90 & 35 \\
\hline
\end{tabular}


Table 2. The composition of synthetic wastewater

\begin{tabular}{|c|c|c|c|c|c|c|c|c|c|}
\hline Stages & $\begin{array}{l}\text { CAF, } \\
\mathrm{mg} / \mathrm{L}\end{array}$ & $\begin{array}{l}\text { MNZ, } \\
\text { mg/L }\end{array}$ & $\begin{array}{l}\text { IBU, } \\
\mathrm{mg} / \mathrm{L}\end{array}$ & $\begin{array}{c}\text { Glucose, } \\
\text { mg/L }\end{array}$ & $\begin{array}{c}\text { Peptone, } \\
\text { mg/L }\end{array}$ & $\begin{array}{c}\text { Lab } \\
\text { Lemco } \\
\text { powder, } \\
\text { mg/L }\end{array}$ & $\begin{array}{c}\text { Ammonium } \\
\text { bicarbonate, } \\
\text { mg/L }\end{array}$ & $\begin{array}{c}\text { Potassium } \\
\text { bicarbonate, } \\
\text { mg/L }\end{array}$ & $\begin{array}{c}\text { Sodium } \\
\text { bicarbonate, } \\
\text { mg/L }\end{array}$ \\
\hline $\begin{array}{c}\text { Stage A } \\
\text { (Days 0-26) }\end{array}$ & - & - & - & 400 & 120 & 80 & 40 & 20 & 20 \\
\hline $\begin{array}{c}\text { Stage B } \\
\text { (Days 26-36) }\end{array}$ & 30 & - & - & 360 & 120 & 80 & 40 & 20 & 20 \\
\hline $\begin{array}{c}\text { Stage C } \\
\text { (Days 38-48) }\end{array}$ & - & 30 & - & 370 & 120 & 80 & 40 & 20 & 20 \\
\hline $\begin{array}{c}\text { Stage A2 } \\
\text { (Days 48-72) }\end{array}$ & - & - & - & 400 & 120 & 80 & 40 & 20 & 20 \\
\hline $\begin{array}{c}\text { Stage D } \\
\text { (Days 72-82) }\end{array}$ & - & - & 30 & 0 & 120 & 80 & 40 & 20 & 20 \\
\hline $\begin{array}{c}\text { Stage E } \\
\text { (Days 85-95) }\end{array}$ & 10 & 10 & 10 & 150 & 120 & 80 & 40 & 20 & 20 \\
\hline
\end{tabular}


Table 3. The details of HPLC analysis

\begin{tabular}{|c|c|c|c|}
\hline $\begin{array}{l}\text { Compound } \\
\text { Parameter }\end{array}$ & Caffeine & Metronidazole & Ibuprofen \\
\hline Column & \multicolumn{3}{|c|}{$\begin{array}{c}\text { ZORBAX Rapid Resolution High Definition column (Agilent), } \\
\text { phase SB-C8, internal diameter }=2.1 \mathrm{~mm}, \text { length }=100 \mathrm{~mm}, \\
\text { particle size }=1.8 \mu \mathrm{m}\end{array}$} \\
\hline Injection volume $(\mu \mathrm{L})$ & 1 & 1 & 10 \\
\hline Eluent & $\begin{array}{c}60 \% \text { ultra-pure } \\
\text { water }+40 \% \\
\text { acetonitrile }\end{array}$ & $\begin{array}{l}50 \% \text { ultra-pure } \\
\text { water }+50 \% \\
\text { methanol }\end{array}$ & $\begin{array}{c}65 \% \text { ultra-pure } \\
\text { water }+35 \% \\
\text { acetonitrile }\end{array}$ \\
\hline Flow rate $\left(\mathrm{mL} \mathrm{min}{ }^{-1}\right)$ & 0.4 & 0.1 & 0.7 \\
\hline Column temperature & $\begin{array}{l}\text { Left side: } 25^{\circ} \mathrm{C} \\
\text { right side: } \\
\text { combined }\end{array}$ & $\begin{array}{l}\text { Left side: } 25^{\circ} \mathrm{C} \text {, } \\
\text { right side: } 25^{\circ} \mathrm{C}\end{array}$ & $\begin{array}{l}\text { Left side: } 25^{\circ} \mathrm{C}, \\
\text { right side: } \\
\text { combined }\end{array}$ \\
\hline $\begin{array}{l}\text { Detector wavelength } \\
\qquad(\mathrm{nm})\end{array}$ & 280 & 292 & 222 \\
\hline Retention time (min) & 0.742 & 3.357 & 4.687 \\
\hline
\end{tabular}


Table 4. The details of IC analysis

\begin{tabular}{|c|c|c|}
\hline $\begin{array}{c}\text { Ion } \\
\text { Parameter }\end{array}$ & Ammonium $\left(\mathrm{NH}_{4}^{+}\right)$ & Nitrate $\left(\mathrm{NO}_{3}{ }^{-}\right)$ \\
\hline Column & $\begin{array}{c}\text { Dionex IonPac CS12A-5 } \mu \mathrm{m} \\
\text { Analytical }(3 \times 150 \mathrm{~mm})\end{array}$ & $\begin{array}{l}\text { Dionex IonPac AS11-HC- } \\
4 \mu \mathrm{m} \text { Analytical }(2 \times 250 \\
\mathrm{mm})\end{array}$ \\
\hline Injection volume $(\mu \mathrm{L})$ & 25 & 2.5 \\
\hline Eluent & $\begin{array}{c}20 \mathrm{mM} \text { Methanesulfonic } \\
\text { acid }\end{array}$ & $\begin{array}{l}30 \mathrm{mM} \text { Potassium } \\
\text { Hydroxide }(\mathrm{KOH})\end{array}$ \\
\hline Flow rate $\left(\mathrm{mL} \cdot \mathrm{min}^{-1}\right)$ & 0.5 & 0.38 \\
\hline $\begin{array}{l}\text { Column temperature } \\
\qquad\left({ }^{\circ} \mathrm{C}\right)\end{array}$ & \multicolumn{2}{|c|}{30} \\
\hline Detection & \multicolumn{2}{|c|}{ Suppressed Conductivity } \\
\hline Suppressor & $\begin{array}{c}\text { Dionex Cation Self- } \\
\text { Regenerating Suppressor } \\
\text { (Dionex ASRS } 3002 \mathrm{~mm} \text { ) } \\
\text { AutoSuppression Recycle } \\
\text { Mode }\end{array}$ & $\begin{array}{c}\text { Dionex Anion Self- } \\
\text { Regenerating Suppressor } \\
\text { (Dionex ASRS } 3002 \mathrm{~mm} \text { ) } \\
\text { AutoSuppression Recycle } \\
\text { Mode }\end{array}$ \\
\hline Applied current, mA & 30 & 29 \\
\hline Storage solution & Eluent & $100 \mathrm{mM}$ Sodium Tetraborate \\
\hline
\end{tabular}


Table 5. The details of TC and TN analysis

\begin{tabular}{|c|c|c|}
\hline $\begin{array}{c}\text { Method } \\
\text { Parameter }\end{array}$ & TC & $\mathbf{T N}$ \\
\hline Carrier gas & \multicolumn{2}{|c|}{ Oxygen $(99.999 \%)$} \\
\hline Detector & $\begin{array}{c}\text { Focus Radiation Non-Dispersive } \\
\text { Infrared }\end{array}$ & $\begin{array}{c}\text { Chemi-luminescence, } \\
\text { Electrochemical }\end{array}$ \\
\hline Combustion method & \multicolumn{2}{|c|}{ High-temperature combustion } \\
\hline $\begin{array}{c}\text { Combustion temperature } \\
\qquad\left({ }^{\circ} \mathrm{C}\right)\end{array}$ & \multicolumn{2}{|c|}{800} \\
\hline Catalyst & \multicolumn{2}{|c|}{ Platinum } \\
\hline Sample volume $(\mu \mathrm{L})$ & \multicolumn{2}{|c|}{250} \\
\hline Rinse volume $(\mu \mathrm{L})$ & \multicolumn{2}{|c|}{2000} \\
\hline Repetitions for TC & $\operatorname{Min} 2, \max 3$. & $\operatorname{Min} 2, \max 3$ \\
\hline
\end{tabular}


Table 6. Average values of TC and TN removal and TSS during different experimental stages.

\begin{tabular}{|c|c|c|c|c|}
\hline \multirow[b]{2}{*}{ Experimental stages } & \multirow{2}{*}{$\begin{array}{c}\text { TC removal } \\
(\%)\end{array}$} & \multirow{2}{*}{$\begin{array}{c}\text { TN removal } \\
(\%)\end{array}$} & \multicolumn{2}{|c|}{ TSS, g/L } \\
\hline & & & $\begin{array}{c}\text { Nitrification } \\
\text { zone } \\
\end{array}$ & $\begin{array}{c}\text { Denitrificatio } \\
\text { n zone } \\
\end{array}$ \\
\hline $\begin{array}{c}\text { Stage A } \\
\text { (Acclimatization) }\end{array}$ & $79.69 \pm 9.34$ & $64.17 \pm 16.33$ & $1.88 \pm 0.68$ & $1.80 \pm 0.67$ \\
\hline $\begin{array}{c}\text { Stage B } \\
(30 \mathrm{mg} / \mathrm{L} \mathrm{CAF})\end{array}$ & $82.09 \pm 1.73$ & $45.45 \pm 3.96$ & $2.03 \pm 0.62$ & $1.82 \pm 0.49$ \\
\hline $\begin{array}{c}\text { Stage C } \\
(30 \mathrm{mg} / \mathrm{L} \mathrm{MNZ})\end{array}$ & $73.68 \pm 6.91$ & $34.72 \pm 6.30$ & $1.99 \pm 0.34$ & $2.03 \pm 0.30$ \\
\hline Stage A2 & $76.41 \pm 12.69$ & $60.70 \pm 26.52$ & $1.59 \pm 0.49$ & $1.52 \pm 0.31$ \\
\hline $\begin{array}{c}\text { Stage D } \\
(30 \mathrm{mg} / \mathrm{L} \mathrm{IBU})\end{array}$ & $60.54 \pm 2.45$ & $42.82 \pm 1.13$ & $1.75 \pm 0.32$ & $1.85 \pm 0.41$ \\
\hline $\begin{array}{c}\text { Stage E } \\
(10 \mathrm{mg} / \mathrm{L} \mathrm{CAF}, 10 \\
\mathrm{mg} / \mathrm{L} \mathrm{MNZ,} 10 \mathrm{mg} / \mathrm{L} \\
\text { IBU) }\end{array}$ & $68.83 \pm 4.05$ & $32.34 \pm 15.22$ & $1.61 \pm 0.19$ & $1.60 \pm 0.16$ \\
\hline
\end{tabular}


Table 7. Removal of emerging pollutants during different experimental stages

\begin{tabular}{ccccccc}
\hline $\begin{array}{c}\text { Experimental } \\
\text { stage }\end{array}$ & Stage B & Stage C & Stage D & \multicolumn{3}{c}{ Stage E } \\
\hline & \multicolumn{7}{c}{ Biodegradation of emerging pollutants, $\%$} \\
Time, days & CAF & MNZ & IBU & CAF & MNZ & IBU \\
3 & 98.34 & 27.44 & 100 & 100 & 56.48 & 83.76 \\
7 & 100 & 12.16 & 100 & 100 & 51.65 & 100 \\
10 & 98.76 & 12.43 & 100 & 100 & 52.07 & 100 \\
Average & $99.03 \pm 0.70$ & $17.34 \pm 7.14$ & $100 \pm 0.0$ & $100 \pm 0.0$ & $53.4 \pm 2.18$ & $94.59 \pm 7.65$ \\
\hline
\end{tabular}




\section{Figures Legends}

Figure 1. Scheme of the CE 705 Activated sludge process bioreactor from GUNT (Germany): 1 tanks for acid and caustic, 2 heating water tank, 3 heater, 4 circulation pump, 5 return sludge pump, 6 treated water tank, 7 secondary clarifier, 8 aeration tank, 9 stirring machines, 10 switch cabinet, 11 process schematic, 12 metering pumps, 13 compressor. Reprinted with permission from GUNT. Copyright 2020 G.U.N.T. Gerätebau GmbH 2020.

Figure 2. TC and TN removal efficiency of the reactor operating without activated sludge.

Figure 3. Comparison of the experimental cumulative distribution function $\mathrm{F}(\mathrm{t})$ obtained for the aeration tank and the ideal CSTR model.

Figure 4. TC and TN removal efficiency in activated sludge bioreactor operating in the absence of emerging pollutants (Stages A and A2) and in the presence of $30 \mathrm{mg} / \mathrm{L} \mathrm{CAF} \mathrm{(Stage} \mathrm{B),} 30 \mathrm{mg} / \mathrm{L} \mathrm{MNZ}$ (Stage C), $30 \mathrm{mg} / \mathrm{L} \mathrm{IBU} \mathrm{(Stage} \mathrm{D)} \mathrm{and} 10 \mathrm{mg} / \mathrm{L} \mathrm{CAF}, 10 \mathrm{mg} / \mathrm{L} \mathrm{MNZ,} 10 \mathrm{mg} / \mathrm{L} \mathrm{IBU}$ (Stage E).

Figure 5. Concentration of $\mathrm{NH}_{4}{ }^{+}-\mathrm{N}$ in activated sludge bioreactor operating in the absence of emerging pollutants (Stage A) and in the presence of $30 \mathrm{mg} / \mathrm{L} \mathrm{CAF} \mathrm{(Stage} \mathrm{B),} 30 \mathrm{mg} / \mathrm{L} \mathrm{MNZ} \mathrm{(Stage} \mathrm{C),} 30 \mathrm{mg} / \mathrm{L}$ IBU (Stage D) and $10 \mathrm{mg} / \mathrm{L} \mathrm{CAF,} 10 \mathrm{mg} / \mathrm{L} \mathrm{MNZ,} 10 \mathrm{mg} / \mathrm{L} \mathrm{IBU} \mathrm{(Stage} \mathrm{E).}$

Figure 6. Concentration of $\mathrm{NO}_{3}{ }^{-}-\mathrm{N}$ in activated sludge bioreactor operating in the absence of emerging pollutants (Stage A) and in the presence of $30 \mathrm{mg} / \mathrm{L} \mathrm{CAF} \mathrm{(Stage} \mathrm{B),} 30 \mathrm{mg} / \mathrm{L} \mathrm{MNZ} \mathrm{(Stage} \mathrm{C),} 30 \mathrm{mg} / \mathrm{L}$ IBU (Stage D) and $10 \mathrm{mg} / \mathrm{L} \mathrm{CAF,} 10 \mathrm{mg} / \mathrm{L} \mathrm{MNZ,} 10 \mathrm{mg} / \mathrm{L} \mathrm{IBU} \mathrm{(Stage} \mathrm{E).}$ 


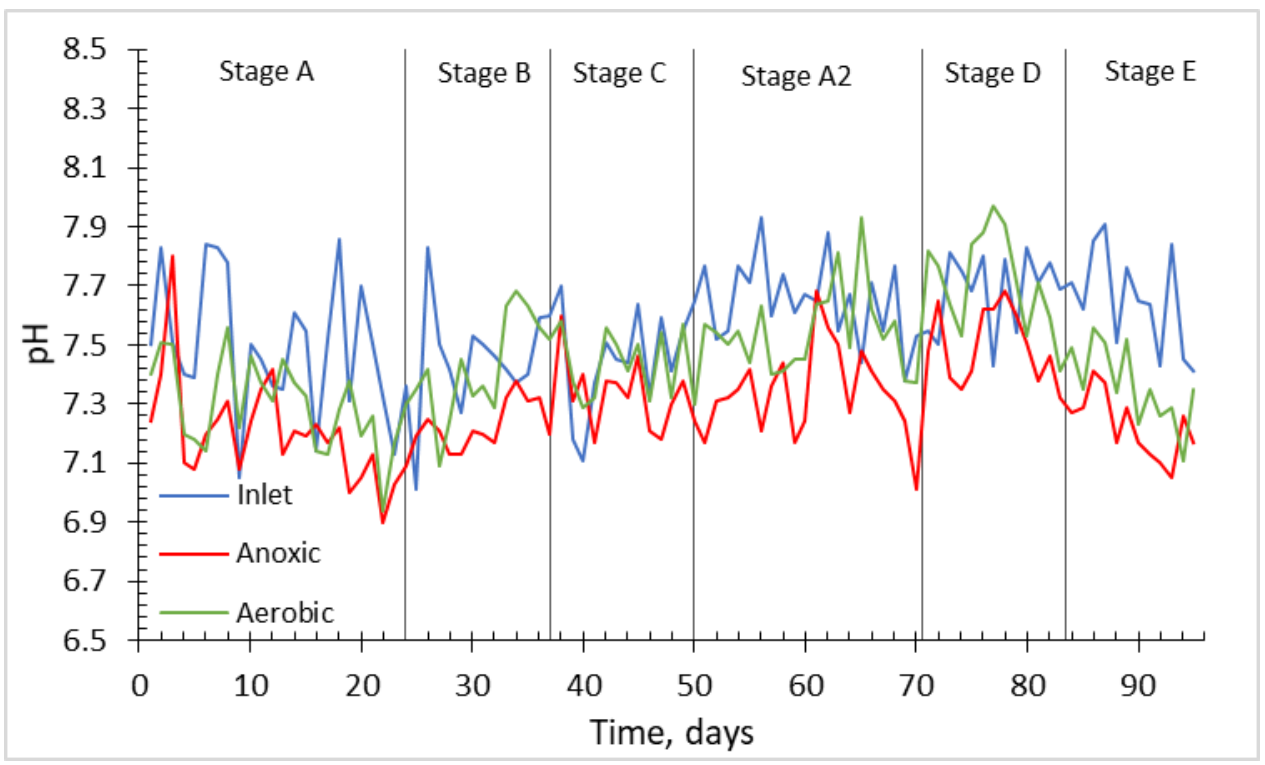

Figure S.1. $\mathrm{pH}$ of activated sludge process in the absence of emerging pollutants (Stages A and A2) and in the presence of $30 \mathrm{mg} / \mathrm{L} \mathrm{CAF}$ (Stage B), $30 \mathrm{mg} / \mathrm{L}$ MNZ (Stage C), $30 \mathrm{mg} / \mathrm{L} \mathrm{IBU} \mathrm{(Stage} \mathrm{D)} \mathrm{and} 10 \mathrm{mg} / \mathrm{L}$ CAF, 10 $\mathrm{mg} / \mathrm{L} \mathrm{MNZ}, 10 \mathrm{mg} / \mathrm{L}$ IBU (Stage E).

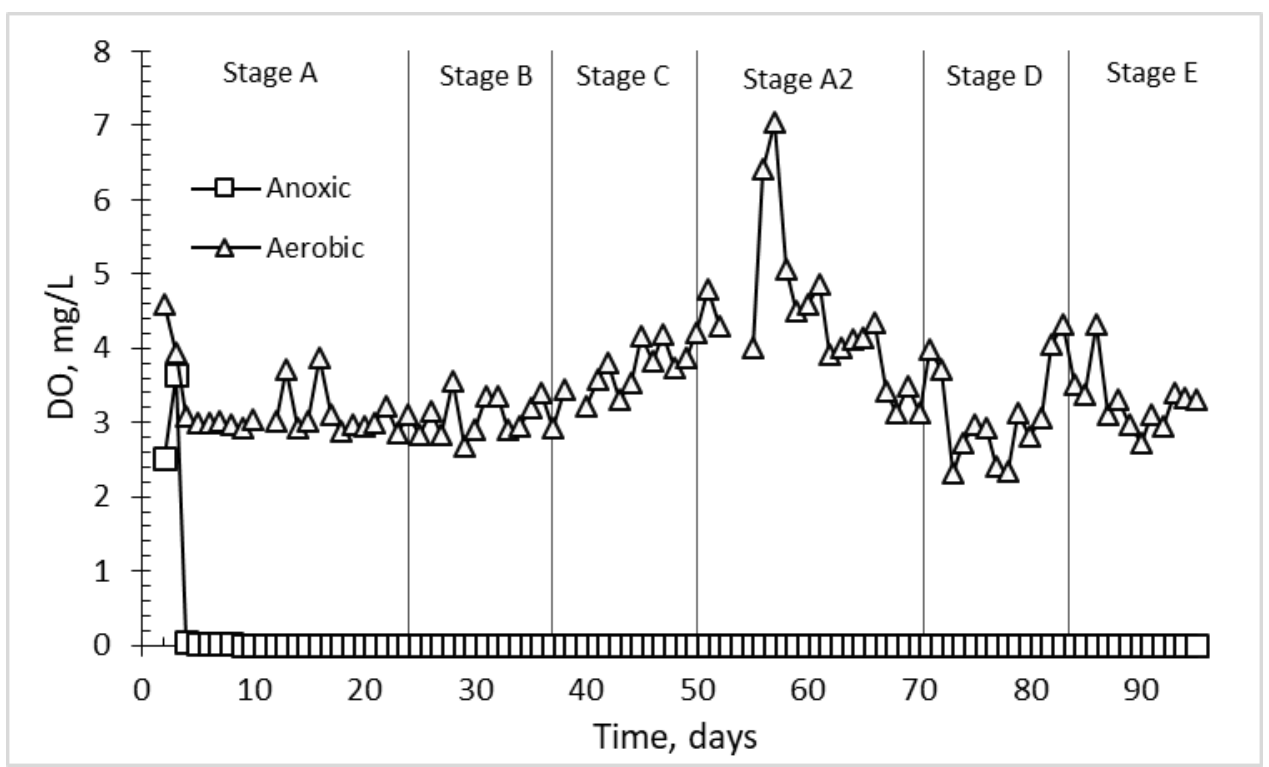

Figure S.2. DO of activated sludge process in the absence of emerging pollutants (Stages A and A2) and in the presence of $30 \mathrm{mg} / \mathrm{L} \mathrm{CAF} \mathrm{(Stage} \mathrm{B),} 30 \mathrm{mg} / \mathrm{L} \mathrm{MNZ} \mathrm{(Stage} \mathrm{C),} 30 \mathrm{mg} / \mathrm{L}$ IBU (Stage D) and $10 \mathrm{mg} / \mathrm{L} \mathrm{CAF}, 10$ $\mathrm{mg} / \mathrm{L} \mathrm{MNZ,} 10 \mathrm{mg} / \mathrm{L}$ IBU (Stage E). 

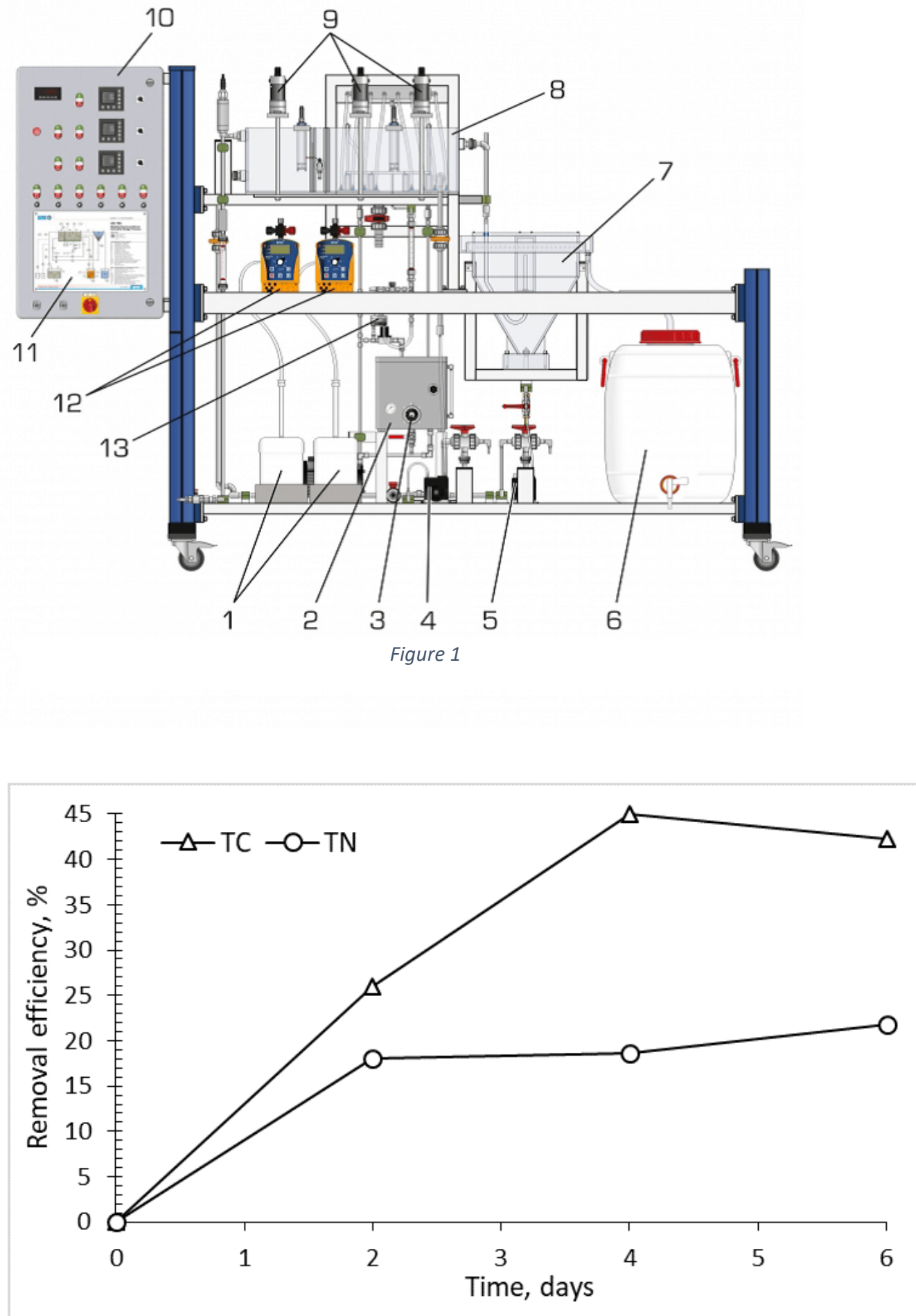

Figure 2 


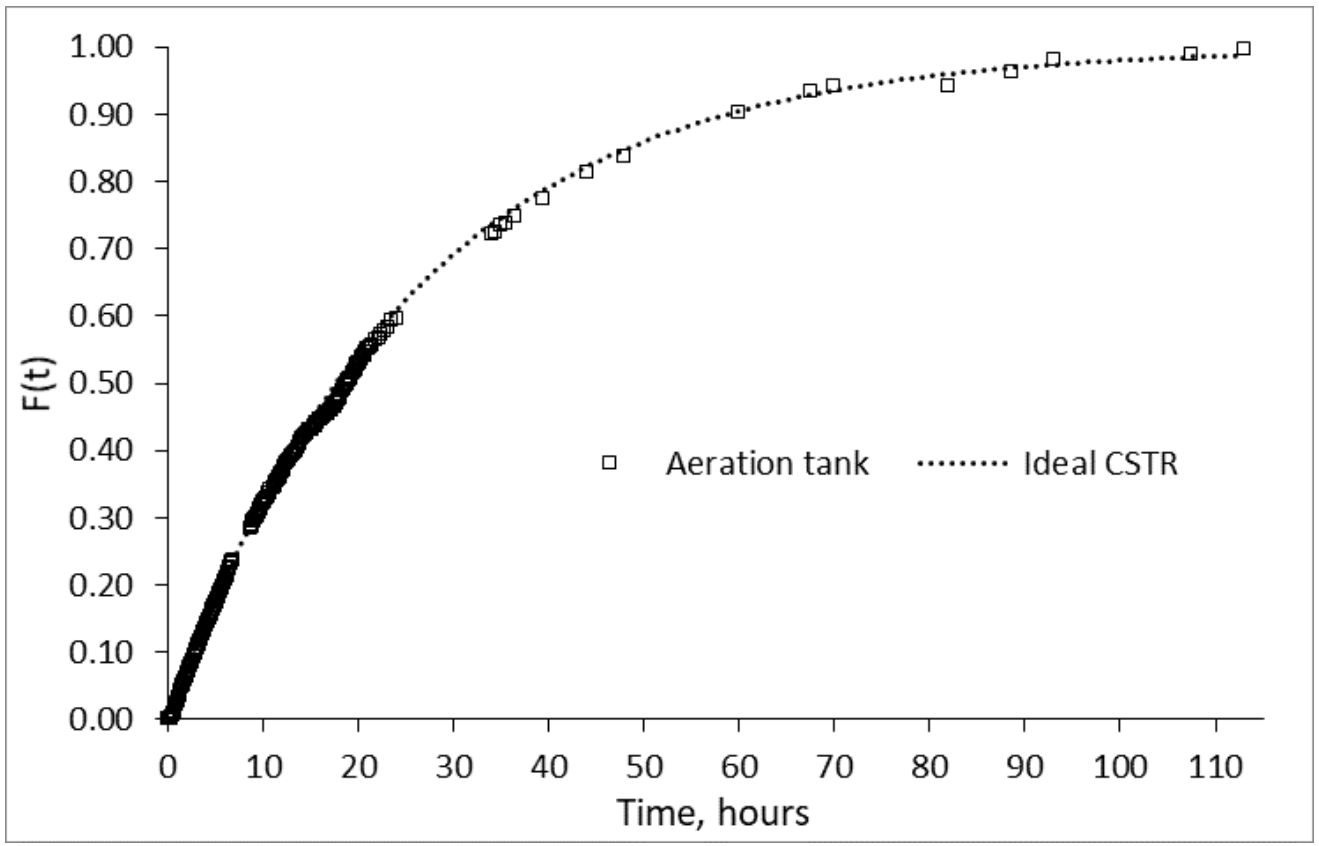

Figure 3

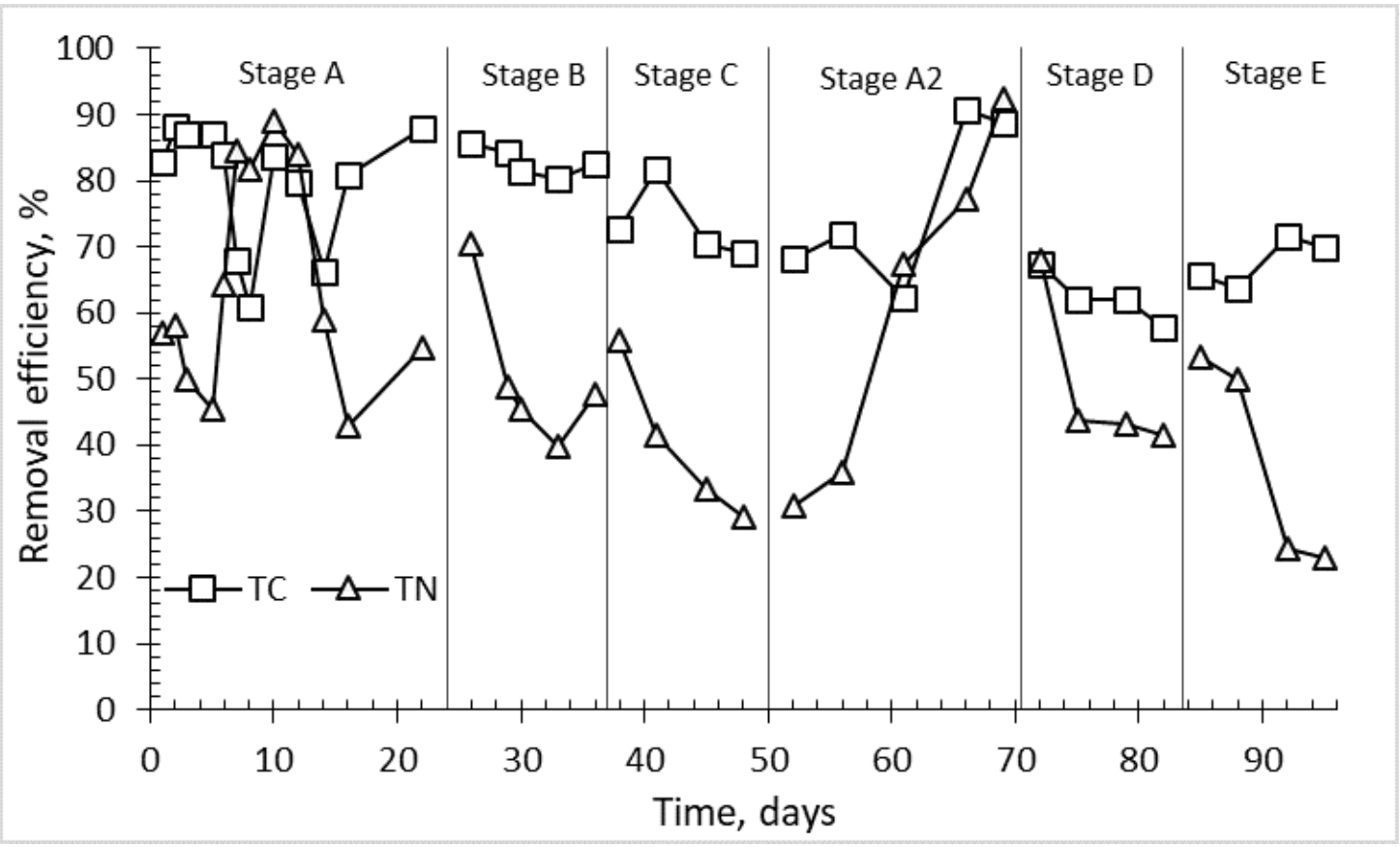

Figure 4 


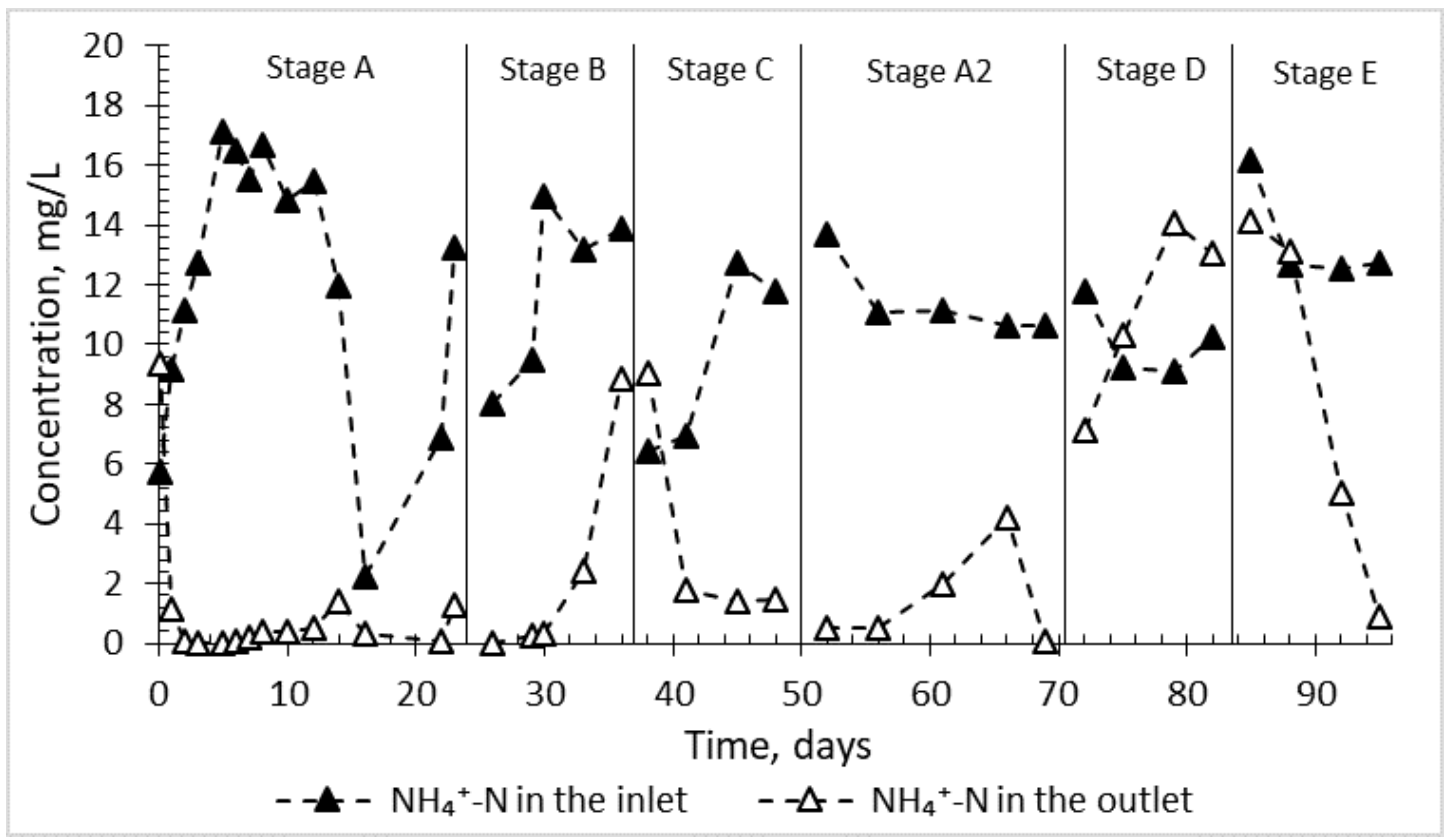

Figure 5

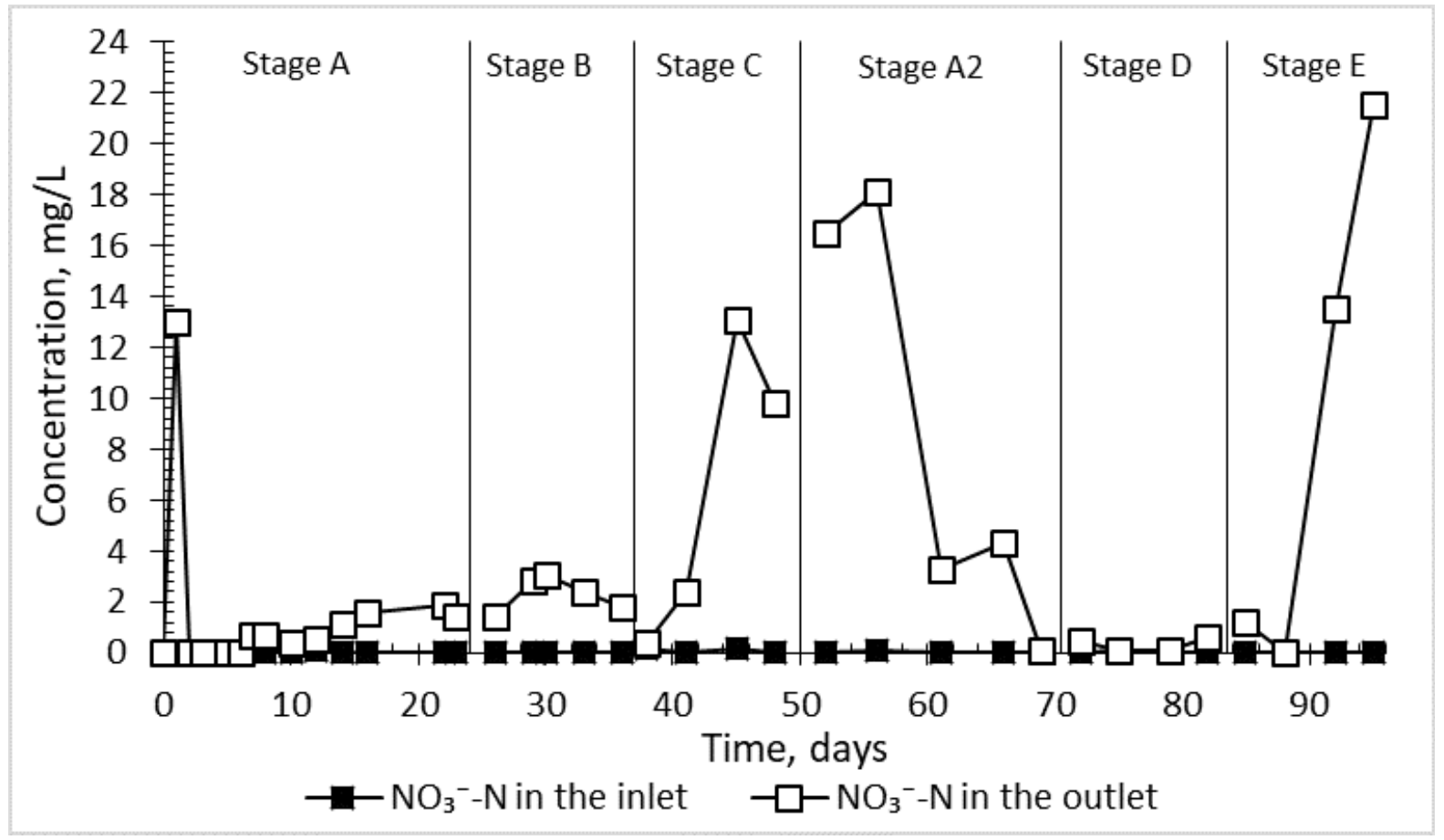

Figure 6 